\title{
Internalization of Literature Values of I La Galigo in International Forum ${ }^{1}$
}

\author{
Achmad Zulfikar \\ International Relations Department \\ Faculty of Social and Political Sciences \\ Universitas Muhammadiyah Yogyakarta \\ Email: apa@kabarfikar.com
}

\begin{abstract}
A cultural values will have benefits when applied directly in the process of interaction among individuals. It is also applicable to the literature of I La Galigo which has been recognized by UNESCO as a Memory of the World. This recognition has implications for the amount of responsibility to disseminate the values of I La Galigo in various aspects. However, this will not be achieved if the political support of the implementation of the regulations are not sufficient to internalize these values. Therefore the recommendation of the authors, should regulationin the South Sulawesi provinceinternalize the values that in turn may empower diplomat candidates from South Sulawesi province to have a provision in the form of literary values of I La Galigo to be applied in international relations. The findings of the authors in the literature ofI La Galigo, there are seven values can be applied in developing relations between nations namely: (1) self-esteem, (2) fairness, (3) wisdom (4) patience, (5) family, (6) generosity, and (7) pride.
\end{abstract}

Keywords: Internalization, I La Galigo, Diplomacy, International Forum

\section{A. Introduction}

Think Globally, Act Locally is a jargon that has been widely used in campaigning environmental and educational issues. I believe the jargon is not only applicable to those issues but can be also suit to promote the value of local culture in the International level. As for our existence in this country is inseparable from the international community in all over the world. The positive effect arising from the interaction that we have had global insight. But what about today? there has been a lot of individuals who have lost their native identity. This is due to another culture has eroded their identity, so that the individual is experiencing an identity crisis.

Identity can actually be developed by strengthening the local culture. The culture that can shape identity may come from the things nearest to us, such as customs, advice and counsel. The one that I want to raise in this discussion are the values learned from I $\mathrm{La}$ Galigo literature. In the works of 6000 pages thick, pretty much described the values that ought to be imitated and applied. But the lack of work that explored the contents of the literature ofI La Galigo causes the values contained therein are not well known by the community so that the values rather considered as a myth.

\footnotetext{
1 Presented in International Congress II of Local Languages of South Sulawesi 2012 (Kongres Internasional II Bahasa-Bahasa Daerah Sulawesi Selatan Tahun 2012) organized by Balai Bahasa Provinsi Sulawesi Selatan dan Provinsi Sulawesi Barat on October, $1^{\text {st }} 4^{\text {th }} 2012$ in Makassar.
} 
Furthermore, I La Galigois a classic literature that used to live in the land of Bugis of South Sulawesi from the 14th century. This work is a literary work of the world's longest known by the term Sureq La Galigo. In 2011, this literary work has been recognized by the United Nations for Educational, Scientific, and Cultural Organization (UNESCO), which stipulates that the script of I La Galigo is a heritage site and was given the award for the Memory of the World (MOW). Departing from extraordinary appreciation of the international community, the authors reveal compelled the great value of I La Galigo literature as a means of disseminating this work in the form of practical and applicable.

One form of the application of the values of I La Galigo literature can be used as a means of diplomacy in international forums. Prior to internalize these values in international forums, of course, necessary preparations for one of them to provide insight to Indonesian diplomats from South Sulawesi to carry out the mission.

\section{B. I La Galigo as the Cultural Product}

Sirtjo Koolhof a Dutch scientist in the International Seminar on I La Galigoheld in Hasanuddin University Makassar on 27 April 2012, state that I La Galigo is often regarded as a history book, but the assumption is wrong because I La Galigois a literary work. As a result we often equate literary works that have great value as a cultural history book that disputed the truth.

Therefore as a work of literature from the 14th century, literature I La Galigo is the result of a culture that has contributed to civilization. This is in line with the views of the experts below.

Koentjaraningrat (1974: 217) explains that culture only humans possess, and grow along with the development of human society. For that Koentjaraningrat using something he calls "cultural framework", which has two aspects, namely the form of culture and cultural content. Referred to as a form of culture is either: (1) a form of ideas (cultural system), which is abstract, (2) behavior (social systems), which are rather concrete, and (3) a physical or objects, which are universal, meaning the seven elements exist in any society in the world. The seven elements are: (1) language, (2) technology system, (3) livelihood systems, (4) social organization, (5) knowledge of the system, (6) religious system, (7) art.

Kroeber and Kluckhorn in Pranowo (1952:86) has collected dozens of definitions of culture, and breaks it down into six categories according to the nature of the definition, namely: (1) a descriptive definition, the definition that emphasizes the elements of culture, (2) historical definition, the definition emphasizes that culture socially inherited, (3) the 
definition of normative definitions emphasize the nature of culture as a rule of life and conduct. On the usefulness of culture in conformity with the environment, solving problems, and learn to live, (5) structural definition, the definition that emphasizes the nature of culture as a system patterned and orderly, (6) the genetic definition, the emphasis on the definition of culture as the work of human being. Based on the grouping of the above it can be seen that culture pervades all aspects and dimensions of human life.

Grouping of cultural definitions made by Nababan (1984) suggests that culture covers all aspects and elements of human life. Nababan cultural definition classifies into four categories, namely (1) the definition of a view of culture as a regulator and tie the community, (2) the definition of a view of culture as the things that human being has acquired through learning or education (nurture), (3) the definition of a view the customs and culture of human behavior, and (4) the definition of a view of culture as a system of communication that people use to gain cooperation, unity, and survival.

Based on the above thoughts, I La Galigo literature classified as a result of the idea of human culture manifested in the form of a literary work and kept together in the community. Furthermore, from the above it can be seen that I La Galigo not just historical archives, but a series of living values has been applied by the community at that time so they feel it is important to preserve in the form of literature that describes the situation and their condition at that time.

\section{Internalization of Traditional Cultural Values in Modern Society}

Applying traditional cultural values such as $L$ La Galigo literature in modern society is a tough challenge. Given the influx of modern culture that actually get rid of the local culture has a right to exist amid the people.

According to Sujatmoko (1987:54), traditional culture is the driving force for a community to thrive. At the cultural level, people will find the key of the spirit and motivation. In addition, creativity and self-confidence will increase, as well as to the community will be embedded character (identity), culture, pride, and dignity.

Further said that to build a genuine community a traditional cultures is needed to establish the identity of the community. The presence of traditional culture is not only to deal with the challenges that exist, but also the purpose and meaning of life.

Actually, the traditional cultural heritage as I La Galigo is a source of inspiration and spirit to develop the identity of people in the South Sulawesi region. When the source is fade away replaced by new values in modern era, then people will in lost original character and identity. 
The fact which has been described previously that traditional cultural values that have been knocked down require major breakthroughs of all elements of society in encouraging the revival of the noble values of the original culture of the community or nation. One of the things that can be done by transforming the way people view about his own culture. One way to change society's view that everything is in the form of traditional ideas, living systems, practices or behaviors even a form of work, often considered old-fashioned and out of date. So they did not consider it useful and feasible for disposal. There is a feeling of inferiority when applying traditional values in everyday life and are considered not to follow developments. This is the mistake of looking at the culture, and that culture tend to follow a mass without a good filter.

According to Muhtamar (2007:124) the shift in perspective on their own culture is only possible if we sincerely retrace traditional traces, both contained in a manuscript or long texts that still exist, as well as studying the phenomenon of tradition in a traditional community of pristine and persisted until now. Critically studying all the variables in it with a particular approach. As well as be wiser in interpreting the contextual, cultural handshake as an attempt to present such a phenomenon developed from the science, technology, life systems, and paradigms.

Efforts to do in the internalization of the traditional cultural values in the modern society, according to the authors can be achieved by at least two ways both socially and politically. Socially, it can be done by the community especially those who are still applying traditional cultural values in order to stay running consistently, but still develop the culture to be more dynamic in order to remain mingled with the development of the broader culture. Politically, is necessary to have political will from the government, in this case the South Sulawesi provincial government to make regulations in the province so that these values can be internalized in many aspects, one of the aspects of the preparation of the prospective diplomats from South Sulawesi province to implement the activities to develop international relations.

As discussed above it can be concluded that the importance of cultural values to be preserved is to have opportunity to develop strong character within the community. By maintaining and preserving cultural values, can be the best basic foundation to build better civilization in the future.

\section{Diplomacy through Culture}


According to Morgenthau (2010:169-173), the quality of a country's diplomacy is one of the nine elements of national power of a country. Of all the factors that led to the strength of a country, the most important is the quality of diplomacy. All the other factors that determine national power can be considered asadditional to determine the strength of the state. In this case, the quality of a country's diplomacy integratedwith other additional factors will determine the country power in international diplomacy.

As has been described above that the quality of a country's diplomacy is one of the important element in measuring a country's national strength. It is a foundation that diplomacy has significance meaning to strengthening the power of Indonesia in the eyes of other countries. In accordance with the description in the beginning, that the values of literature I La Galigo are cultural values that ought to be internalize by the diplomats in order to equip them with cultural insight. It departs from the urgency of diplomacy itself is an attempt by a country to achieve its interests in international relationship. Departing from both the urgency and cultural diplomacy will require real effort to synergize the two by way of using one type of diplomacy, namely, cultural diplomacy.

According to Holsti (1984:82-83), cultural diplomacy is an attempt of a nation to fight for its national interests through cultural dimensions such as, both micro such as education, science, sports, and the arts, and the macro according to the characteristics of the main, such as propaganda, and others, that in the conventional sense can be considered as non-political, economic, or military.

Furthermore, according to Warsito and Wahyuni (2007: 4-5) reveals that the object and purpose of cultural diplomacy is to influence public opinion (the other countries) to support a particular foreign policy.

The first example of cultural diplomacy that also pinned the award of puppets (wayang)as a Masterpiece of the Oral and Intangible Heritage of Humanity by UNESCO in 2003. The purpose of this award was to gain the attention of the community and the artistic heritage of world culture specific and high value, and urged the state government to take administrative and legal measures to preservetheir cultural heritage.

The second example was the cultural diplomacy by the Japanese government. After the protests in various countries due to Japan's diplomatic strategy based on economic advantage, so there was a change in strategy in 1977. Japanese Prime Minister Fukuda launched a foreign policy based on cooperation not only in economic, but also involves culture. From the change in Japan's foreign policy is being accepted in many countries and cooperating well. 
From the above discussion, it can be concluded that the quality of a country's diplomacy is one indicator of the country's national strength. However, diplomacy will work better when collaborating with culture, as Japan did. In addition, the presence ofI La Galigo literature that has been recognized as a UNESCO Memory of the World in 2011, will be the same even with the puppet popularity today, especially after getting recognition from UNESCO in 2003. This will happen if there is a good cooperation between the government and the community.

\section{E. Characteristics of the Ideal Diplomat}

According to Morgenthau (2000:108), a diplomat is a person appointed by a state to conduct diplomacy with another state or international organization. The primary task is to protect the interests of the country and its citizens.

Based on the mandate carried out by the diplomat, of course, we need a picture of someone who can carry out their duties properly and perfectly. However, the perfection of the work of a diplomat is determined by his personal qualities. So it is necessary for the proper placement of a diplomat to carry out their duties. As for some expert opinion that indicates the shape or characteristics of the ideal diplomat. Callierres in Irsan (2010:42) states that an ideal diplomat should be honest to others so that credibility is not in doubt.

Furthermore Talleyrand in Irsan (2010:43) states that a diplomat should have two categories of quality. First, have an attitude of prudence, humility, good memory, and have the ability to evaluate strengths and weaknesses of a negotiation, and resolve to uphold the honor of their country and to protect the interests of his country. Second, have the analytical skills of the linkages political relationship based perspective, having the ability to understand the substance of a problem quickly and accurately, and have a broad way of thinking to encapsulate all the details into a general state information for the benefits of their country.

Jules Cambon in Irsan (2010:43) believes that the moral authority to be the most important quality for a good diplomat. Earnest Satow in Irsan (2010:43-44) says that some of the qualities should be possessed an ideal diplomat, always an earnest attempt to put himself in the position to be faced and tried to imagine what he wants, do, and say. While Harold Nicholson in Irsan (2010:44) explains that an ideal diplomat should have seven qualities are qualities: honesty, accuracy, calm, steady temperament, patience, humility, and loyalty.

The characteristics of the ideal diplomat who has been described above is the point of the character possessed by a diplomat. Furthermore, will the value of literary excavation of $I$ La Galigo as proof that a literary work has relevance to the present. 


\section{F. Internalization of $I \mathrm{La}$ Galigo Literature Values in Shaping Diplomat Character}

Based on the above presentation, the values of literature of I La Galigo are cultural values that are important to be preserved in order to build the character of the community. These values are also been the basis for building a better future civilization.

Furthermore, the urgency to collaborate with these cultural diplomacy is recommended to strengthen the quality of diplomacy conducted by Indonesia, because the quality of a country's diplomacy is one indicator of a country's national strength.

In this case, the values of I La Galigo literature that can be internalized in the character of a diplomat can be found through analysis of the texts of I La Galigo. Manuscripts analyzed by the authors is part 3 of 6 volumes of literary alignment results of $I$ La Galigo. The purpose of the alignment of the text published here in this book is a simple form of literature of I La Galigoliterary. simple in terms of reduced number of pages, language tailored to the needs to be more easily digested. Nonetheless, the themes and its substance maintained.

The author chose part 3 of 6 volumes, as discussed in this section many traces Sawerigading adventure that is a reflection of the relationships between nations at that time, however, these values can be applied across the ages so it can be used as a reference to develop the character of the diplomats in the present time. The findings from the analysis of the script ofI La Galigoare as follows:

\section{- Self-Esteem}

During the sailing of Sawerigading, once reject to dropped by in Kelling because the king of Kelling was very arrogant and ignorant to set his words. (P. 7)

\section{- Kinship}

After all the food was served, the door was closed, drums and gongs Manurung sung the golden gong struck as the announcement that the great man began to eat. Sawerigadingwashed his hands, and his wife and son. The three of them then eat together in a platter. (P. 31)

\section{- Generosity}

Sawerigading suggested to his parents that all people in need around Aleluwuk, Watamparek to lands under its rule are collected for a given property. Sawerigading impressed with the state of the person who was always helping people in need. In nature they are very happy soul. (P. 33) 


\section{- Patience}

Batara Lattuk and his wife listened to the stories of his sonhappily, except the story of $L a$ Tenroaji.Batara Lattuk very angry to hear it. Swearing, spitting his arrogance shows how brave he was to his son. Prosperous country should be destroyed and his wife made in Aleluwuk cook, so he felt it due to his arrogance. Sawerigadinghave no heart to do it, because La Maddaremmeng was a cousin of the king once with Kelling, while La Tenroaji wife, Daeng Sagala was the daughter of the king of KellingI La Galigo. (P. 35)

\section{- Pride}

Wearing oversized clothes characteristic of each area, guests will pass through bamboo stake that has been decorated and also greet with royal ceremony. (P. 64)

\section{- Wisdom}

Wero, the kingBataras's envoy Batara deliberately enrages La Pananrang then specify the port taxes they should pay.La Pananrang and La Sinilele listening with smile. They then tell a story since the first time they set sail track distant lands, had never been ordered to pay the taxes. La Pananrang and La Sinilele rejected talk of war and asked for them, because the only people who lose are willing to accept.

Both of king's envoy notice a war to them. La Sinileleand La Pananrangwisely responding to this challenge. Both said how could they take the fight, while they are not against in talks. But both the older cousin asks Sawerigading second messenger that says size will fulfill the treasure, but not as a tribute, because the king's sister never give tribute where they anchored. Giving it as an offering to Sri Manurungnge majesty. (P. 89-90)

\section{- Honesty}

... the king's sons were saying, they can not play around with words, abstinence for those in Luwuk and Tompo Tikkaspell a lie word. (P. 117)

\section{G. Diplomat I La Galigoin the International Forum}

Based on the findings from the analysis of the script I La Galigo above, it found seven values that can be applied to the (1) self-esteem, (2) fairness, (3) wisdom (4) patience, (5) family, (6) philanthropy and (7) pride. These values can be applied in relations among the nations, but of course first be applied to individual Indonesian diplomat.

If any sample taken from the seventh grade in the relations among the nations, for example: the value of wisdom. If in an international forum, a meeting that determines the boycott action against a State for the mistakes that are not proven. Indonesian diplomats then obliged to explore the truth of the information in advance, then give a wise decision. Due to 
the impact as a result of the decision of a handful of people will decide the fate of the people of the country. So that this attitude needs to be taken in order to provide objective opinion on an issue.

\section{H. Conclusion}

From the above discussion, the process of internalizing the values of literature of $I \mathrm{La}$ Galigo in international forums can be inferred through several phases, among others, (a) realized I La Galigo as a literary work is not a history book, so that the work is not continuously debated the truth, but can be learned as a lesson, (b) modern society should be aware that the values of traditional culture is not something to be denied its existence and even used as a reference for the development of character and identity, (c) the importance of internalizing these values as with forms of collaboration between the ability of a country's diplomacy and the use of culture as a source of value that can be applied, and (d) the internalization of seven values from the literature of I La Galigo should start from the will and confidence to run before the individual diplomat further apply in relations among the nations.

However the implementation of the internalization of the values of I La Galigo will not run properly, if it does not get political support in the form of regulation made to instill these values. It is hoped the South Sulawesi provincial government preserving the culture of South Sulawesi seriously, which is now eroded by the times.

\section{Bibliography}

Chambert-Loir, Henri, dan Hasan Muarif Hambary (ed.). 1999. Panggung Sejarah: Persembahan Kepada Prof. Dr. Denys Lombard. Jakarta: Yayasan. Pustaka Obor Indonesia.

Effendi, Tonny Dian. 2011. Diplomasi PublikJepang: Perkembangan dan Tantangan. Bogor: Ghalia Indonesia.

Holsti, K.J. 1984. International Politics: A Framework for Analysis Third Edition. New Delhi: Prentice Hlml of India.

Irsan, Abdul. 2010. Peluang dan Tantangan Diplomasi Indonesia. Jakarta: Himmah Media Utama.

Jurnal Ilmu Pengetahuan Budaya Wacana Vol. 13 No. 2. 2011. Multiculturalism. Jakarta: Universitas Indonesia.

Kuntjaraningrat. 1979. Pengantar Antropologi Budaya. Jakarta: Aksara Baru. 
Muhtamar, Shaff. 2007. Masa Depan Warisan Luhur Kebudayaan Sulsel. Makassar: Pustaka Refleksi.

Morgenthau, Hans. J., 2010. Politik Antar-Bangsa (Edisi Revisi). Jakarta: Yayasan Pustaka Obor Indonesia.

Ram, Nunding, Yusuf, Lely Yuliani Said. 2011. I La Galigo \#3. Makassar: Pustaka Refleksi.

Satow, Sir Earnest. 1922. A Guide to Diplomatic Practice. New York: Longman Green \& Co.

Suastika, I Made, I Nyoman Kutha Ratna, I Gede Mudana. 2011. Jelajah Kajian Budaya. Bali: Pustaka Larasan.

Sukawarsini Djaelantik. 2008. Diplomasi Antara Teori dan Praktik. Yogyakarta: Graha Ilmu.

UNHAS. Pemikiran La Galigo Universal. (http://www.unhas.ac.id/content/pemikiran-lagaligo-universal), diakses tanggal: 19 September 2012.

Warsito, Tulus, dan Wahyuni Kartikasari. 2007. Diplomasi Kebudayaan: Konsep dan Relevansi bagi Negara Berkembang: Studi Kasus Indonesia. Yogyakarta: Penerbit Ombak. 